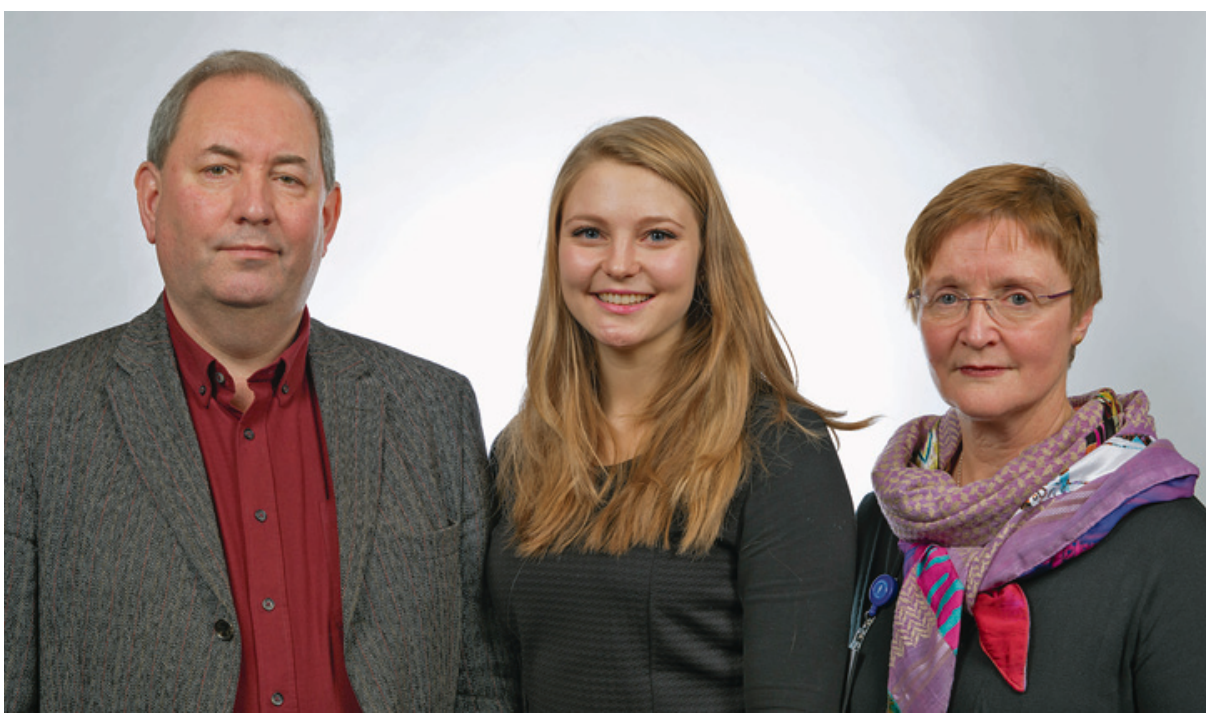

Professor Lars A. Akslen, forskerlinjestudent Maria Ryssdal Kraby og professor Anna M. Bofin. Foto: Jørn Ove Sæternes

MIN FøRSTE PUBLIKASJON

\title{
Nye prognosemarkører ved brystkreft
}

Brystkreft kan deles inn i subgrupper på grunnlag av nye funn om angiogenese, ifølge en ny norsk studie. Dette kan gi mer informasjon om prognose og ha betydning for hva slags behandling pasienter bør få.

Nydanning av kar, angiogenese, er en forutsetning for tumorvekst og metastasering. Dette skjer ved at tumorceller stimulerer omliggende kapillærer til prolifererasjon slik at svulstene får sin egen blodforsyning. I en norsk studie som nylig er publisert i Journal of Clinical Pathology, beskriver forfatterne tre metoder for å måle angiogenese i kreftsvulster: mikrokartetthet, prolifererende mikrokartetthet og vaskulær proliferasjonsindeks (1). Målet var å sammenligne angiogenesen $i$ to subtyper av brystkreft, luminal A-type og basal fenotype, der den førstnevnte har best prognose.

Studien ble utført på et utvalg av brystkrefttilfeller som forskningsgruppen tidligere har klassifisert i molekylære subtyper. Immunhistokjemiske metoder ble brukt for å synliggjøre blodkar på snitt fra 62 svulster av hver type. Hovedfunnet er at høy mikrokartetthet er assosiert med dårligere prognose i luminal A-subtypen, men ikke i basal fenotype. Prolifererende mikrokartetthet og vaskulær proliferasjonsindeks var høyere i brystkreftsvulster av basal fenotype, men var ikke assosiert med prognose.

- I denne studien var de fleste luminal A-svulstene histopatologisk grad 3. Flere studier er nødvendig for å avklare om mikrokartetthet gir prognostisk tilleggsinformasjon i alle grader av luminal A-type, sier Maria Ryssdal Kraby, som er førsteforfatter og forskerlinjestudent ved Norges teknisknaturvitenskapelige universitet (NTNU).
En videre inndeling i prognostiske subgrupper kan bidra til å identifisere svulster med spesielt god prognose og dermed bidra til økt individualisering av behandling, sier hun.

\section{Brystkreftforskning}

Forskningsgruppen Breast Cancer Subtypes ved Norges teknisk-naturvitenskapelige universitet ble etablert i 2009 og ledes av professor Anna Mary Bofin ved Institutt for laboratoriemedisin, barne- og kvinnesykdommer og professor Lars Johan Vatten ved Institutt for samfunnsmedisin. Gruppen kombinerer data fra befolkningsundersøkelser og registerdata med histopatologiske og molekylærpatologiske metoder for å finne ny kunnskap om risiko og prognose ved brystkreft. Gruppen har et nært samarbeid med professor Lars A. Akslen, leder av Center for Cancer Biomarkers. Senter for fremragende forskning i Bergen. Studier av angiogenese i ulike subtyper av brystkreft ga en unik mulighet for samarbeid mellom forskningsmiljøene i Bergen og Trondheim.

\section{Kaveh Rashidi}

Tidsskriftet

\section{Litteratur}

1. Kraby MR, Krüger K, Opdahl S et al. Microvascular proliferation in luminal $\mathrm{A}$ and basal-like breast cancer subtypes. J Clin Pathol 2015; 68: 891-7.
Ordforklaringer:

Mikrokartetthet: Antall blodkar per kvadratmillimeter i tumor. Bestemmes ved immunhistokjemi, der von Willebrands faktor farger cytoplasma i endotelcellen.

Prolifererende mikrokartetthet: Antall prolifererende blodkar per kvadratmillimeter i tumor. En prolifererende endotelcelle, som er del av et prolifererende blodkar, uttrykker von Willebrands faktor i cytoplasma og proliferasjonsmarkøren Ki67 i nukleus.

Vaskulær proliferasjonsindeks: Ratioen mellom antall prolifererende kar og totalt antall kar i tumor. 